2. Assuming that a danger of tuberculous infection from milk exists, how can it be prevented? Pasteurisation has had a great deal said in its favour, and efficient pasteurisation does destroy the tubercle bacillus. But pasteurisation, as commonly carried out, is uncertain in its action, and there are various other objections to this process. These, however, will be dealt with in another article.

"Certified" milk is another solution that has been suggested. This means that the milk is produced under stringent conditions as to cleanliness of the animals, milkers, cowhouses, milking, \&c., the herds are tuberculin-tested, and the milk is cooled, bottled, and packed in ice for transit. A good deal has been said about the growth of the certified-milk-depôt movement in America, but it is not perhaps realised that this has been forced upon her populace by the deplorable condition of the general milk supply there. Moreover, certified milk, unless subsidised by public funds or private benevolence, can do nothing to help those to whom a pure milk supply is of the greatest importance, viz., the poor; for it is admitted that the cost of certified milk must be from $8 d$. to rod. per quart - only a few of even the well-to-do will pay such a price! When, a year ago, the price of milk was, in stress of circumstances, raised from $4 d$. to $5 d$. per quart, what an outcry there was; and every practical dairyman knows that the consumption of milk fell off, and, what is more, has not risen again on the recent decline in price to the former level. Further, if a certified milk trade became general, enormous numbers of cases of bottles would have to be handled by the railway companies, and greatly increased truck capacity would be necessary to deal with them. These and other practical points are not always realised by the armchair reformer.

3. The great question at issue is not so much whether a very carefully dairied milk, with a low bacterial content, distributed in bottles under ideal conditions, would, or would not, be an advantage to the community as a whole, but rather whether the existing milk supply in general is the cause of such damage to the public health as is frequently so confidently asserted. Save, perhaps, as regards tuberculous infection, which, from what has been stated above, cannot be regarded as a serious menace, the general milk supply is better now than it has ever been, and it is steadily improving. Two factors, which are in the region of practical politics, would undoubtedly improve matters without revolution and unnecessary expense. These are (a) cooperation between the farmers in a district and the treatment of their milk (cooling, \&c.) at a central depôt from which it would be distributed either to the towns around, or to the railway for forwarding to a distance by regular, fast, and properly equipped milk trains, all farms being under proper official inspection; (b) the elimination of the street dealer or hawker by the abolition of all station trade, and the absorption of the smaller dealers into a few large companies, so that there is but one middleman between the farmer and the consumer.
It will not be possible to speak definitely of the value of "synthesised milk," a preparation of soya beans, recently placed on the market, until its nutritional value has been ascertained.

R. T. Hewlett.

\section{JUBILEE OF THE PHILOSOPHICAL INSTITUTE OF CANTERBURY, NEW ZEALAND.}

THE Philosophical Institute of Canterbury, New Zealand, celebrated its jubilee on August $3^{\circ}$ by holding a conversazione in the Art Gallery, in Christchurch. The institute was established on August 30 , I862, twelve years after the foundation of the Canterbury Settlement. Sir Julius Von Haast, who had only recently arrived in the colony, was the principal leader of the movement to form the institute, and he devoted to it the remarkable energy and enthusiasm with which he founded Canterbury Museum and made it the best institution of the kind in New Zealand. He was elected the first president of the institute, and was one of its most prominent officers until his death, many years afterwards.

The institute made an excellent start on its career. It was ambitious, and it is characteristic of the spirit which animated the colonists of those days that it made up its mind at once to do something quite practical. It announced that it wished to take part in the development of the resources of the province, and to help the settlers by disseminating amongst them useful knowledge. It held its first business meeting, which was numerously attended, in November, 1862, and it listened to the reading of papers on the growth of thistles, the manufacture of the native flax (Phormium tenax), and other practical subjects.

Besides contributing largely to the Transactions of the New Zealand Institute, the institute has undertaken publications on its own account. Amongst these are the "Index Faunæ Novæ Zealandiæ "(r897), edited by Captain Hutton, and "The Subantarctic Islands of New Zealand" (rgog), a large work in two volumes, containing reports on a scientific expedition to the Campbell and Auckland Islands, south of New Zealand. This work is the result of an enterprise which the institute took in hand in 1906, when it urged upon the Government the desirableness of extending the magnetic survey of New Zealand to the different groups of islands that lie south of the mainland. The Otago Institute gave its support, and the proposal was approved by the New Zealand Institute; and later on the scope of the scheme was extended to include investigations into the geology, zoology, and botany of the islands.

The jubilee celebration in August last was attended by a brilliant gathering. Dr. L. Cockayne, F.R.S., the president, whose researches in botany, especially in regard to ecology, are well known in the United Kingdom and other countries, and who has taken a prominent part in the institute enterprises in recent years, presided. In an

NO. 2245, VOL. 9o] 
address, he showed how the institute had originated, and he sketched its career; he then dealt with the position of the man of science in regard to humanity and the world's progress. $\mathrm{He}$ said that it is true that man does not live and move and have his being at the dictates of science, but it is to science that civilisation owes its present position, and in the thickly populated centres man's very existence depends upon the progress of science. The works of science are so wrapped up in the ordinary man's daily life that he not only does not feel grateful to the scientific man, but frequently ignores his very existence. The man in the street, in fact, although he may be well informed in other directions, forgets, or never knows, that applied science must be based upon discoveries in pure science, which at first may appear to have no importance whatever for the human race. The progress of the world depends upon the number, the quality, and the zeal of the men of science. They are the ultimate makers of the people's wealth and the rulers of the people's destinies; and they must always be highly trained and enthusiastic in their work.

The Mayor of Christchurch, in a short address, congratulated the institute, and also congratulated Dr. Cockayne on being elected a Fellow of the Royal Society. Mr. G. M. Thomson, as the representative of the Parliament of New Zealand, read congratulatory messages from the Prime Minister of the Dominion and from the Hon. R. H. Rhodes to the institute and to Dr. Cockayne as the winner of the Hector medal for his researches in botany. Mr. Thomson added that he had been asked to present to Dr. Cockayne this first Hector medal, struck in honour of the late Sir James Hector. The medal had not arrived in the Dominion, and could not be handed to the recipient just then, but it carried with it a grant to help in the recipient's future work. Dr. Cockayne's researches had cost him large sums of money, and he had great pleasure in asking that gentleman to accept a sum which would help him in the great work he still had in hand.

Dr. Cockayne returned thanks, and after other addresses had been given, the gathering was brought to an end.

\section{PLAICE FISHERIES OF THE NORTH SEA.}

THE tenth meeting of the International Council for the Study of the Sea was held at Copenhagen in April last, and the Procès-Verbaux have recently been published. The most important subject considered was the general report on the plaice fisheries of the North Sea, which is being prepared by Prof. Heincke, of Heligoland. Only the first section of this report was, however, ready at the time of the meeting, and it was decided that another meeting should take place at the end of September for the further consideration of the matter. The section of the report laid before the meeting by Prof. Heincke in April was based chiefly on the special market statistics of plaice landed, the greater part of the material being derived from English ports. The results of the work of the special steamers remain to be considered.

From an economic point of view the study of the plaice question is undoubtedly the most important work which the council has undertaken, and it is to be regretted that such great delay has occurred in the preparation of the report. Prof. Heincke cannot be blamed for this delay, which seems to have been due to faulty organisation on the part of the council, and to a want of appreciation of the magnitude of the task. The work might well have occupied the entire time and energy of one man with a staff of trained assistants under him, and it was clearly impossible that it could be carried out within a reasonable time, in addition to his other duties, by the director of the Heligoland Biological Station. If some of the money which has been spent on the organisation and formal administration of the Council and on the less important parts of the programme had been employed to enable Prof. Heincke to devote his whole time and energy to the task and to obtain adequate assistance in doing the detailed work, the position at the present time would have been much more satisfactory.

\section{THE PLASTIC ART OF PALAOLITHIC MAN.}

$W^{E}$ learn from The Times of October $3 \mathrm{I}$ that Count Begouen, the well-known investigator of prehistoric archæology, has made a remarkable discovery in the cave known as Tus Ditboubert, in the district of MontesquieuAventès (Ariège), where three months ago he found mural paintings of animals, presumably of Aurignacian age. On October 1o the Count and his son broke through a mass of stalactites, and in the new gallery thus exposed found two clay figures, respectively 26 in. and 30 in. long, representing a bull and cow bison. They appear to have been attached originally to a rock, as one side is rough while the other is completely modelled. They are nearly perfect; the only damage that they had received was that one of the horns of the female bison and its tail had been broken off; the tail was, however, found on the floor of the cave. A third small clay figure was also found, but it was so roughly modelled as to make it impossible to say what it represents.

In passing through the galleries the explorers found many footprints of bears and human beings. In one of the galleries, where there was a number of otherwise indistinguishable marks on the floor, some fifty imprints of human heels were discovered, and Count Begouen, in his communication to the Academy of Inscriptions of Paris on October 30, suggested that these may represent traces of ritual observances or dances similar to those which have been oberved among the savage tribes of the present day in Australia and Africa.

This is the first time clay figures of Palæolithic date have been discovered, and it affords one more example of the wonderful finds that have been yielded by the French caves. A very large number

NO. 2245, VOL. 90] 